\title{
Inhibitory effects of tiotropium on rhinovirus infection in human airway epithelial cells
}

\author{
Mutsuo Yamaya*, Hidekazu Nishimura*, Yukimasa Hatachi ${ }^{\mp}$, Hiroyasu Yasuda ${ }^{+}$, \\ Xue Deng $^{+}$, Takahiko Sasaki ${ }^{\S}$, Hiroshi Kubo* and Ryoichi Nagatomi ${ }^{\dagger}$
}

\begin{abstract}
Infection by rhinoviruses (RVs) causes exacerbations of chronic obstructive pulmonary disease (COPD). The long-acting anti-cholinergic agent tiotropium reduces the frequency of COPD exacerbations, but the inhibitory effects of tiotropium on the COPD exacerbations induced by RVs are unclear. Likewise, the effects of tiotropium on RVs infection remain to be studied.
\end{abstract}

To examine the effects of tiotropium on RV infection and RV infection-induced airway inflammation, human tracheal epithelial cells were infected with a major group RV, type $14 \mathrm{RV}$ (RV14).

RV14 infection increased the viral titre and the amount of pro-inflammatory cytokines, including interleukin (IL)-1 $\beta$ and -6 , in supernatant fluids and the amount of RV14 RNA in cells. Tiotropium reduced RV14 titres, RNA and cytokine concentrations, and susceptibility to RV14 infection. Tiotropium reduced the expression of intercellular adhesion molecule (ICAM)-1, the receptor for RV14, and the number of cellular acidic endosomes, which allow RV14 RNA to enter the cytoplasm. Tiotropium inhibited the activation of nuclear factor- $\mathrm{k}$ proteins, including $\mathbf{p} 50$ and p65, in the nuclear extracts, and it increased the cytosolic amount of inhibitory кВ- $\alpha$.

Tiotropium may inhibit RV14 infection by reducing the levels of ICAM-1 and acidic endosomes and may also modulate airway inflammation in rhinovirus infection.

KEYWORDS: Airway epithelial cell, inflammatory cytokine, intercellular adhesion molecule, rhinovirus

$\mathbf{T}$ he long-acting anti-cholinergic agent tiotropium improves symptoms and lung function in patients with chronic obstructive pulmonary disease (COPD) [1]. In addition, tiotropium reduces the frequency of exacerbations in patients with COPD [1]. These clinical benefits of tiotropium may be related to various effects of the agent, including bronchodilating effects [1], the reduction of airway smooth muscle hypertrophy, and the inhibition of mucus hypersecretion and goblet cell metaplasia [2].

Rhinoviruses (RVs) are the main cause of the common cold and they are also responsible for the most common acute infection illnesses in humans [3]. In addition, RVs are associated with exacerbations of inflammatory chronic pulmonary diseases, such as COPD [4]. Several mechanisms of RVinduced exacerbations of these diseases have been proposed, including virus-induced mucus hypersecretion, airway inflammation [4], and smooth muscle contraction. RV infection induces the production of cytokines and monokines, including interleukin (IL)-1, -6 , and $-8[5,6]$. These cytokines and monokines have pro-inflammatory effects $[4,7]$, and they may also be involved in the pathogenesis of RV infections and infection-induced COPD exacerbations. Tiotropium inhibits the production of pro-inflammatory cytokines and monokines, including IL-6 in mouse lungs, and reduces the number of neutrophils in bronchoalveolar lavage fluid in a mouse model of COPD [7]. However, tiotropium does not reduce sputum IL-6 levels in COPD patients [8]. Thus, the inhibitory effects of tiotropium on airway inflammation have not been well studied.

The major group of RVs enters the cytoplasm of infected cells after binding to the receptor known as intercellular adhesion molecule (ICAM)-1 $[9,10]$. It has been suggested that the entry of the RNA from this group of RVs into the cytoplasm of the infected cells is mediated by a destabilisation due to receptor binding and by endosomal
AFFILIATIONS

*Dept of Advanced Preventive Medicine for Infectious Disease, ${ }^{\text {s}}$ Dept of Respiratory Medicine, Tohoku University School of Medicine,

\#Virus Research Center, Clinical Research Division, Sendai National Hospital,

${ }^{+}$Dept of Innovation of New Biomedical Engineering Center, Tohoku University,

${ }^{f}$ Medicine and Science in Sports and Exercise, Tohoku University Graduate School of Medicine, Sendai, and "Dept of Respiratory Medicine, Graduate School of Medicine Kyoto University, Kyoto, Japan.

\section{CORRESPONDENCE}

M. Yamaya

Dept of Advanced Preventive

Medicine for Infectious Disease

Tohoku University Graduate School of Medicine

2-1 Seiryo-machi

Aoba-ku

Sendai

980-8575

Japan

E-mail: myamaya@med.tohoku.ac.jp

Received:

April 142011

Accepted after revision:

Nov 142011

First published online:

Feb 232012 
acidification [9]. A variety of agents, including glucocorticoids, the macrolide antibiotics bafilomycin and erythromycin, the proton pump inhibitor lansoprazole, and the $\beta_{2}$-agonist procaterol inhibit infection by the major group of RVs by reducing ICAM-1 expression or by increasing endosomal $\mathrm{pH}$ [11-13]. Tiotropium has been reported to reduce ICAM-1 expression in the hepatocellular cell line, Hep2 [14], and is partially related to the inhibition of respiratory syncytial virus infection. However, the inhibitory effects of tiotropium on RV infection are unclear.

We studied the effects of a long-acting anti-cholinergic agent, tiotropium, on RV infection in primary cultures of human tracheal epithelial cells. We also examined the effects of tiotropium on the production of ICAM-1 and on endosomal $\mathrm{pH}$ to clarify the mechanisms responsible for the inhibition of RV infection.

\section{MATERIALS AND METHODS}

\section{Human tracheal epithelial cell culture}

Human tracheal surface epithelial cells were isolated and cultured as described previously [6]. The cells were plated at $5 \times 10^{5}$ viable cells per $\mathrm{mL}$ in plastic tubes with round bottoms (Becton Dickinson, Franklin Lakes, NJ, USA). The tubes were kept stationary, and the cells were immersed in $1 \mathrm{~mL}$ of Dulbecco's modified Eagle's Medium and Ham's F-12 medium (50/50, vol/vol) containing 2\% ultroser G (USG; Pall BioSepra, Cergy-Saint-Christophe, France), and were then cultured at $37^{\circ} \mathrm{C}$ in $5 \% \mathrm{CO}_{2} / 95 \%$ air in the incubator.

To enhance type-14 RV (RV14) release from the cells, cells were cultured in tubes by rolling $[3,6]$. Therefore, to study the effects of tiotropium on the release of RV and cytokines, RV RNA replication, and susceptibility to virus infection, we cultured the cells in tubes by rolling [6]. In contrast, to study the effects of tiotropium on nuclear factor (NF)- $\kappa \mathrm{B}$ activation before RV infection, cells were cultured in tubes under stationary conditions [6]. To examine the effects of rolling, we also studied the effects of tiotropium on NF- $\kappa B$ subunits in the nuclear extracts of the cells cultured by rolling, because cells in the tubes were cultured by rolling after RV infection. Furthermore, acidic endosomes could be observed in the cells living on coverslips in stationary Petri dishes. Therefore, cells used for measuring acidic endosomes were cultured under stationary conditions [6].

Furthermore, to measure virus release from physiological differentiated cells, cells were cultured for 7 days on a filter membrane (Millicell $\mathbb{R}$ CM inserts, $0.45 \mu \mathrm{m}$ pore size and $0.6 \mathrm{~cm}^{2}$ area; Millipore Products Division, Billerica, MA, USA) coated with collagen gel (PureCol ${ }^{\circledR}$; INAMED Corporation, Santa Barbara, CA, USA), as described previously [15]. Culture medium $(400 \mu \mathrm{L})$ was supplied from the basolateral side of the cell sheets through the filter membrane, and the cells were cultured with air-interface methods [15].

Tracheas for cell cultures were obtained after death from 50 patients (mean \pm SEM age $70 \pm 2$ yrs, 34 female, 16 male). No patients were complicated with bronchial asthma, but eight patients were complicated with COPD. Before being hospitalised for the condition that caused death, all of the COPD patients had been treated with tiotropium, but the tiotropium treatment was stopped more than 7 days before death because the patients could not inhale it. From the 50 patients, 13 were ex-smokers and 37 had never smoked. This study was approved by the Tohoku University ethics committee (Sendai, Japan).

\section{Culture of human embryonic fibroblast cells}

Human embryonic fibroblast cells (HFL-III cells, Riken Bio Resource Center Cell Bank, Cell No: RCB0523; Tsukuba, Japan) were cultured in flasks ( $25 \mathrm{~cm}^{2}$ surface area; Becton Dickinson) and were then plated in plastic dishes (MICROTEST ${ }^{\mathrm{TM}}$ Tissue Culture Plate, 96 well; Becton Dickinson) or in plastic tubes with round bottoms. The cells were then cultured at $37^{\circ} \mathrm{C}$ in $5 \%$ $\mathrm{CO}_{2} / 95 \%$ air [6].

\section{Viral stocks}

Type 14 RV (RV14) stocks were prepared from a patient with a common cold by infecting human embryonic fibroblast cells, as previously described [16]. We used RV14 stocks that were passaged three to five times.

\section{Detection and titration of viruses}

RV14 in supernatant fluids was detected and titrated using the end-point method [17] by infecting replicate confluent human embryonic fibroblast cells in 96-well plastic dishes with serial 10 -fold dilutions of virus-containing supernatant fluids, as previously described [6]. The presence of the typical cytopathic effects of RV was monitored in all replicate cells for 7 days (168 h) [6]. On the basis of these data, the 50\% tissue culture infective dose (TCID50) was calculated as previously described [16]. The rates were expressed as TCID50 units $\cdot \mathrm{mL}^{-1}$ per $24 \mathrm{~h}$ [6].

\section{Quantification of RV RNA}

To quantify RV RNA and ribosomal RNA (18S, rRNA) expression in human tracheal epithelial cells after RV infection, two-step real-time quantitative RT-PCR using the Taqman technique (Applied Bissystems, Bedford, CA, USA) was performed with a TaqMan ${ }^{\circledR}$ Gene Expression Master Mix (Applied Biosystems) using methods described by NoLAN et al. [18], as previously reported [6].

In the first step in quantifying RV RNA, cDNA was transferred from RV RNA using the QuantiTect Reverse Transcription Kit (Qiagen, Tokyo, Japan) and the RV reverse primer (5'- CGGACACCCAAAGTAGTCGGT -3').

In the second step, real-time PCR was performed using cDNA from the RV RNA and the TaqMan ${ }_{\circledR}$ Gene Expression Master Mix. The cDNA sample $(2 \mu \mathrm{L})$ was mixed with TaqMan Gene Expression Master Mix $(10 \mu \mathrm{L})$, forward primer (5'- GCACTTCTGTTTCCCAGGAGC-3'; $0.5 \mu \mathrm{L}$ ), reverse primer (5' - CGGACACCCAAAGTAGTCGGT $\left.-3^{\prime} ; 0.5 \mu \mathrm{L}\right)$, Taqman probe RV14 (5'-(FAM) CCTTTAACCGTTATCCGCCA (TAMRA)-3'; $0.5 \mu \mathrm{L})$, and RNase-free water $(6.5 \mu \mathrm{L})$.

To quantify the rRNA, the conversion of rRNA to cDNA and real-time PCR were performed using the same two-step process described above. To quantify rRNA expression, a forward primer (5'- GCACTTCTGTTTCCCAGGAGC-3'), reverse primer (5'- CGGACACCCAAAGTAGTCGGT-3'), and Taqman probe (5'-(FAM) CCTTTAACCGTTATCCGCCA (TAMRA)-3') were designed for the rRNA. 
To obtain quantitative data, the minimum number of PCR cycles required to detect the fluorescent signal was defined as the cycle threshold $(\mathrm{C} \tau)$ of RV RNA and rRNA from the cells, and quantitative data were obtained as described previously [6].

\section{Viral infection of the epithelial cells}

A stock solution of RV14 $\left(100 \mu \mathrm{L}\right.$ in each tube, $1.0 \times 10^{4}$ TCID50 units per $100 \mu \mathrm{L}, 5.0 \times 10^{-2}$ TCID50 units per cell) was added to the human tracheal epithelial cells in the tubes [6], except where other virus doses are indicated. After incubation for $1 \mathrm{~h}$ at $33^{\circ} \mathrm{C}$, the cells were rinsed with PBS and then fed with fresh medium and cultured at $33^{\circ} \mathrm{C}$ by rolling, except where other conditions are indicated.

\section{Treatment with tiotropium}

To examine the effects of tiotropium, cultured cells from the same donors were treated with either tiotropium $(0.1 \mu \mathrm{M}$, supplied from Boehringer-Ingelheim Pharma $\mathrm{GmbH} \& \mathrm{Co}$, Ingelheim am Rhein, Germany) or a vehicle $(0.001 \%$ of $0.01 \mathrm{~N}$ HCL) from 3 days (72 h) before RV14 infection until the end of the experimental period [6], except where other concentrations or treatment periods are indicated.

To examine the concentration-dependent effects of tiotropium on RV14 infection, cells were treated with tiotropium at concentrations ranging from $10 \mathrm{pM}$ to $10 \mu \mathrm{M}$.

Furthermore, to examine the direct interaction of tiotropium with the virus, cells were pretreated with tiotropium $(0.1 \mu \mathrm{M})$ and tiotropium was removed immediately prior to virus infection. The cells were cultured in the medium in the absence of tiotropium during and after virus infection, and the supernatant fluids were collected after virus infection.

To examine the effects of tiotropium in the cells cultured on filter membranes, culture medium containing tiotropium $(0.1 \mu \mathrm{M}, 400 \mu \mathrm{L})$ was supplied from the basolateral side of the CM inserts in the dishes [15].

To examine the effects of tiotropium on ICAM-1 mRNA expression in the cells and the concentration of a soluble form of ICAM-1 (sICAM-1) in the supernatant fluids, the cells were pretreated with tiotropium $(0.1 \mu \mathrm{M})$ from 3 days before RV14 infection.

To examine the concentration-dependent effects of tiotropium on acidic endosomes, cells were treated with tiotropium at concentrations ranging from $1 \mathrm{nM}$ to $10 \mu \mathrm{M}$. Likewise, to examine the time-dependent effects of tiotropium on acidic endosomes, the cells were treated with tiotropium $(0.1 \mu \mathrm{M})$ for time periods ranging from 0 to 3 days $(72 \mathrm{~h})$.

\section{Collection of supernatant fluids for measurements}

The time course of viral release, using previously described methods, was examined in the cultured cells [6]. To measure RV14 release during the first $24 \mathrm{~h}$, three separate cultures were used from the same trachea. We collected the supernatant fluids at 1, 12 or $24 \mathrm{~h}$ after RV14 infection. We also collected supernatant fluids at 3,5 and 7 days $(72,120$ and $168 \mathrm{~h}$, respectively). At 1, 3 and 5 days (24, 72 and $120 \mathrm{~h}$, respectively) after infection, supernatant fluids were collected and fresh medium was replaced, and the cell culture was continued.
Likewise, to examine the effects of tiotropium on the secretion of IL-1 $\beta,-6$ and -8 , supernatant fluids were collected just before infection and 1, 3 and 5 days (24, 72 and $120 \mathrm{~h}$, respectively) after RV14 infection.

In order to measure virus release to the apical side of the cell layers cultured on filter membranes, airway surface liquid (ASL) was collected by washing the apical surface of the layers with $350 \mu \mathrm{L}$ of medium containing 2\% USG, as previously described [19]. We collected ASL at 1, 3, 7 and 5 days (24, 72, 120 and $168 \mathrm{~h}$, respectively) after infection.

\section{Effects of tiotropium on susceptibility to RV infection}

The effects of tiotropium on the susceptibility to RV14 infection were evaluated as previously described [6]. Epithelial cells were pretreated with tiotropium $(0.1 \mu \mathrm{M})$ or vehicle from 3 days $(72 \mathrm{~h}$ ) before infection. The epithelial cells were exposed to serial 10-fold dilutions of RV14 at a dose ranging from $10^{1}$ to $10^{5}$ TCID50 units $\cdot \mathrm{mL}^{-1}$ in medium that contained tiotropium or vehicle for $1 \mathrm{~h}$ at $33^{\circ} \mathrm{C}$. After exposure to RV14, fresh medium with no tiotropium was added. The cells in the tubes were then cultured at $33^{\circ} \mathrm{C}$ by rolling.

We collected the supernatant fluids at 1 and 3 days (24 and $72 \mathrm{~h}$, respectively) after RV14 infection and measured the RV titres in the supernatant fluids with the human embryonic fibroblast cell assay, described above, to assess whether infection occurred at each dose $\left(10^{1}, 10^{2}, 10^{3}, 10^{4}\right.$ or $10^{5}$ TCID50 units $\cdot \mathrm{mL}^{-1}$ ) of RV14 [6].

\section{Measurement of ICAM-1 expression}

The mRNA of ICAM-1 was examined with two-step real-time RT-PCR analysis using the methods described above (Quantification of RV RNA) with a forward primer (5'- GCACTTCTGTTTCCCAGGAGC-3') and a reverse primer (5'- CGGACACCCAAAGTAG TCGGT -3'). A Taqman probe (5'-(FAM) CCTTTAACCGTTATCCGCCA (TAMRA)-3') was designed for ICAM-1. The concentration of sICAM-1 in the supernatant fluids was measured with an enzyme immunoassay [6].

\section{Measurement of changes in acidic endosomes}

The distribution and the fluorescence intensity of acidic endosomes in the cells were measured as previously described with the LysoSensor DND-189 dye (Molecular Probes, Eugene, OR, USA) [6]. Live-cell imaging was performed with the cells on coverslips in Petri dishes, which were observed with a fluorescence microscope (Olympus IX70; Olympus Co. Ltd, Tokyo, Japan). The fluorescence intensity was calculated using

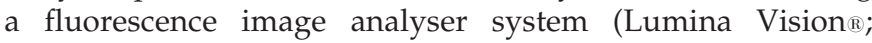
Mitani Co. Ltd, Fukui, Japan). The fluorescence intensity of the acidic endosomes was measured in 100 human tracheal epithelial cells, and the mean value of the fluorescence intensity was expressed as the percentage of the control value compared with the fluorescence intensity of the cells before any treatment.

We studied the effects of a long period of treatment with tiotropium $(0.1 \mu \mathrm{M}, 72 \mathrm{~h})$ on acidic endosomes, because the cells were pretreated with tiotropium for 3 days $(72 \mathrm{~h})$ before RV14 infection, except when we examined the time-dependent effects of tiotropium. 


\section{Measurement of cytokine production}

We measured IL-1 $\beta,-6$ and -8 in supernatant fluids using specific ELISAs [6] in duplicate human tracheal epithelial cells cultured in plastic tubes at all time-points.

\section{$N F-\kappa B$ assay}

Nuclear extracts from human tracheal epithelial cells were prepared using a TransFactor extraction kit (BD Bioscience/ CLONTECH, Mountain View, CA, USA). The presence of the translocated p50, p65 and c-Rel subunits was assayed using a TransFactor Family Colorimetric Kit-NFkB (BD Bioscience/ CLONTECH) according to the manufacturer's instructions, as previously described [6]. The results were expressed as optical

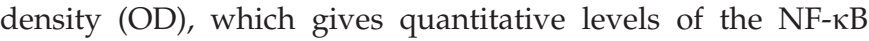
subunits [6].

\section{Western blot analysis}

Western blot analysis for the degradation of inhibitory $\kappa \mathrm{B}-\alpha$ $(\mathrm{I} \kappa \mathrm{B}-\alpha)$ and the analysis of the amount of phosphorylated I $\mathrm{B}-\alpha$ $(\mathrm{p}-\mathrm{I} \kappa \mathrm{B}-\alpha)$ and $\beta$-actin were performed using the methods described previously [6]. Total cellular proteins were obtained by harvesting and lysing human tracheal epithelial cells that were cultured in the presence or absence of tiotropium $(0.1 \mu \mathrm{M}$ or $10 \mu \mathrm{M}, 72 \mathrm{~h}$ ) before RV14 infection. The blots were rewashed with Tween Tris-buffered saline (TTBS; SigmaAldrich, St Louis, MO, USA) and chemiluminescence was detected using an Amersham ECL Plus Western blotting detection kit (GE Healthcare, Waukesha, WI, USA) and a LAS1000 luminescent image analyser (Fujifilm, Tokyo, Japan).

\section{Statistical analysis}

The results were expressed as the mean \pm SEM. Statistical analyses were performed using a one-way ANOVA. Subsequent post hoc analyses were made using Bonferroni's method. For all analyses, values of $p<0.05$ were assumed to be significant. The number of donors (tracheae) from which the cultured epithelial cells were used is given as n.

\section{RESULTS}

\section{Effects of tiotropium on RV infection in human tracheal epithelial cells}

Exposing confluent human tracheal epithelial cell monolayers to RV14 $\left(5.0 \times 10^{-2}\right.$ TCID50 units per cell) consistently led to infection. No virus could be detected at $1 \mathrm{~h}$ after infection; however RV14 was detected in the culture medium at $12 \mathrm{~h}$, and the viral content progressively increased between 1 and $12 \mathrm{~h}$ after infection (fig. 1a). Evidence of continuous viral production was obtained by demonstrating that each of the supernatant fluids collected during either 1 day (12- $24 \mathrm{~h}), 1$ to 3 days $(24-72 \mathrm{~h}), 3$ to 5 days $(72-120 \mathrm{~h}$ ), or 5-7 days (120$168 \mathrm{~h}$ ) after infection contained significant levels of RV14 (fig. 1a). The viral titre levels in the supernatant fluids increased significantly with time for the first 3 days $(72 \mathrm{~h}$, $p<0.05$ by ANOVA). Furthermore, in the tracheal cells from subjects whose cells were infected with RV14, the supernatant fluids collected during 1 to 3 days (24-72 h) after infection contained consistent levels of RV14 (4.79 $\pm 0.25 \log$ TCID50 units. $\mathrm{mL}^{-1}$ per $24 \mathrm{~h}, \mathrm{n}=50$ ).

Treatment of the cells with tiotropium $(0.1 \mu \mathrm{M})$ significantly decreased the viral titres of RV14 in supernatant fluids from
$12 \mathrm{~h}$ after infection compared with the titres in the cells treated with vehicle (fig. 1a).

RV14 titre levels in the supernatant fluids of the cells from the 13 ex-smokers collected 1-3 days (24-72 h) after infection did not differ from those of the 37 patients who had never smoked $\left(4.81 \pm 0.25\right.$ versus $4.77 \pm 0.26 \log$ TCID50 units $\cdot \mathrm{mL}^{-1}$ per $24 \mathrm{~h}$, respectively; $\mathrm{p}>0.20)$.

RV14 titre levels in the supernatant fluids of the cells from the eight patients complicated with COPD did not differ from those of the 42 patients without COPD (data not shown). 10 patients were complicated with lung diseases, including lung cancer $(n=3)$, idiopathic pulmonary artery hypertension (IPAH, $n=3)$, idiopathic pulmonary fibrosis (IPF, $n=2)$, and pneumonia $(n=2)$. RV14 titre levels in the supernatant fluids of the cells from these patients did not differ from those of the other 40 patients without lung diseases (data not shown). No virus was detected in the supernatant fluids after infection using ultraviolet-inactivated RV14 (data not shown).

Treatment with tiotropium $(0.1 \mu \mathrm{M})$ for 3 days $(72 \mathrm{~h})$ did not change viability $(99 \pm 1 \%$ versus $98 \pm 1 \%$ tiotropium versus vehicle, respectively, $\mathrm{n}=5 ; \mathrm{p}>0.50)$, as assessed by the exclusion of trypan blue. Furthermore, until 7 days (168 h) after the start of the cell culture, cells formed confluent sheets in the tubes at the same time-point in both the culture medium containing vehicle and the medium containing tiotropium $(0.1 \mu \mathrm{M})$. The cell number of the confluent sheets cultured in the medium supplemented with tiotropium $(0.1 \mu \mathrm{M})$ did not differ from the number in the medium supplemented with vehicle $\left(2.1 \pm 0.3\right.$ versus $2.2 \pm 0.3 \times 10^{6}$ of cells per tube in tiotropium versus vehicle, respectively, $n=5 ; p>0.50)$. Treatment with tiotropium $(0.1 \mu \mathrm{M})$ for 3 days $(72 \mathrm{~h})$ did not alter the lactate dehydrogenase $(\mathrm{LDH})$ concentration $(33 \pm 3$ versus $34 \pm 3 \mathrm{IU} \cdot \mathrm{L}^{-1}$ per $24 \mathrm{~h}$ in tiotropium versus vehicle, respectively, $n=5 ; p>0.50$ ) when the $\mathrm{LDH}$ concentrations were measured in the supernatant fluids 3 days $(72 \mathrm{~h}$ ) after tiotropium treatment.

Tiotropium inhibited RV14 infection in a concentrationdependent manner. The maximum effect was obtained at 1.0 and $10 \mu \mathrm{M}$ and the minimum effect was obtained at $33 \mathrm{pM}$ (fig. 1b).

When the cells were pretreated with tiotropium $(0.1 \mu \mathrm{M}$ for 3 days) and tiotropium was removed just prior to virus infection, RV14 virus titres in the supernatant fluids of the cells pretreated with tiotropium were significantly lower than those of the cells pretreated with vehicle at 1, 3 and 5 days (24, 72 and $120 \mathrm{~h}$ ) after infection (fig. 1c). By contrast, RV14 titres in the supernatant fluids collected at 7 days $(168 \mathrm{~h})$ after infection from the cells pretreated with tiotropium did not differ from those from the cells pretreated with vehicle (fig. 1c).

When the cells were cultured on filter membranes and exposed to the same concentration of $\operatorname{RV} 14(100 \mu \mathrm{L}$ in each filter membrane, $5.0 \times 10^{-2}$ TCID50 units per cell for $1 \mathrm{~h}$ ) as were the cells in the tubes, RV14 was detected in the ASL at $24 \mathrm{~h}$, and the viral content progressively increased between 24 and $72 \mathrm{~h}$ after infection (fig. 1d). Evidence of continuous viral production was obtained by demonstrating that each of the ASLs collected at $1,3,3-5$ or $5-7$ days $(24,72,72-120$ or $120-168$ h) 

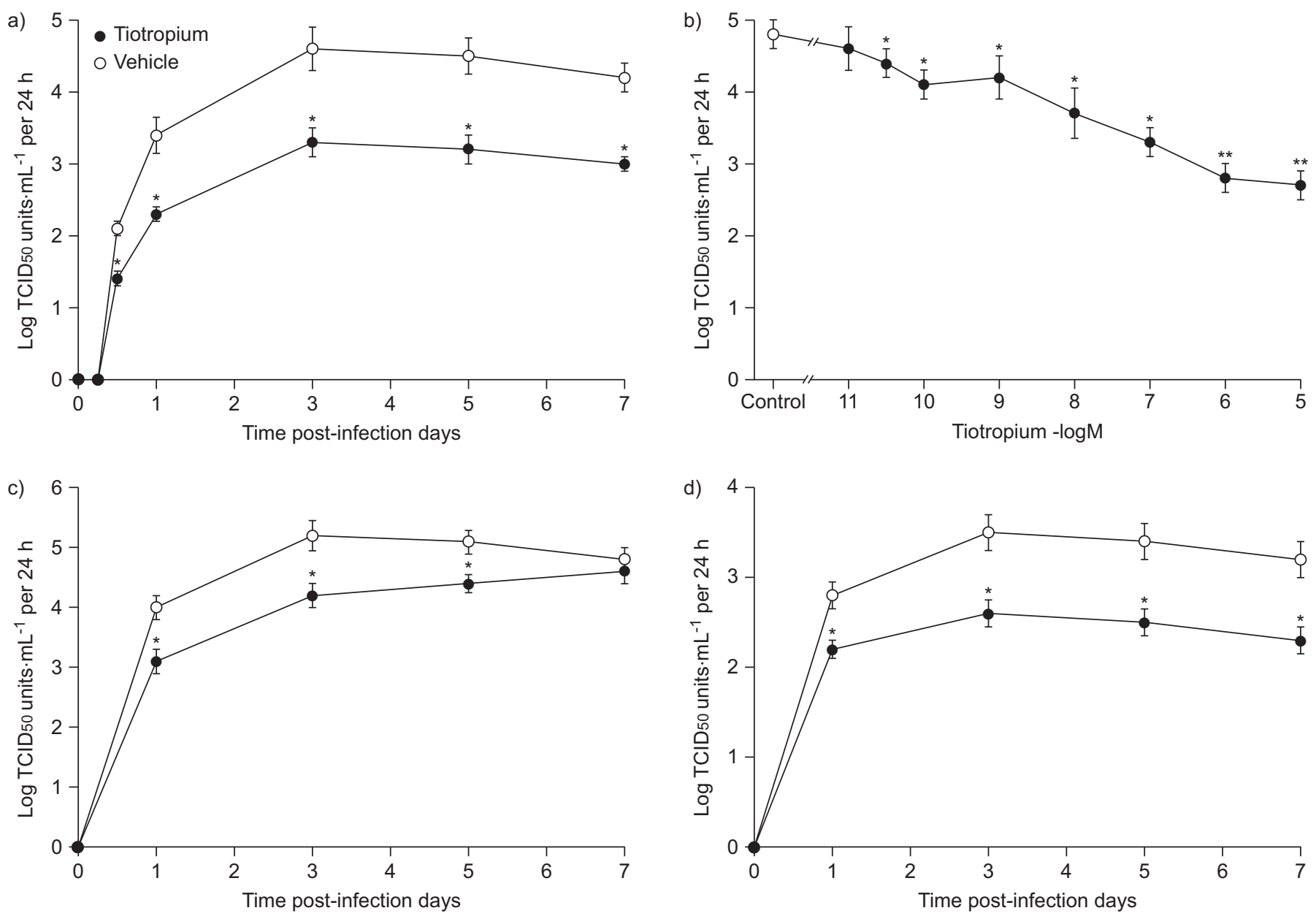

FIGURE 1. a) Time course for viral release in the supernatant fluids of human tracheal epithelial cells obtained at different times after exposure to $5.0 \times 10^{-2} 50 \%$ tissue culture infective dose (TCID50) units.cell ${ }^{-1}$ type- 14 rhinovirus (RV14) in the presence of tiotropium $(0.1 \mu \mathrm{M})$ or a vehicle $(0.001 \%$ of $0.01 \mathrm{~N} \mathrm{HCl)}$. The rates of change in the RV14 concentration in the supernatant fluids are expressed as TCID50 units. $\mathrm{mL}^{-1}$ per $24 \mathrm{~h}$. b) Concentration-response effects of tiotropium on viral release in supernatant fluids collected between 1 and 3 days (24-72 h) after infection. c) The time course of viral release in supernatant fluids of human tracheal epithelial cells obtained at different times after RV14 infection in the presence of tiotropium or a vehicle. d) The time course of viral release in airway surface liquid of human tracheal epithelial cells cultured on filter membranes, obtained at different times after RV14 infection in the presence of tiotropium or a vehicle. Data are presented as mean \pm SEM from a) six tracheae (two exsmokers and four nonsmokers); b) five tracheae (at 10, 33 and $100 \mathrm{pM}$ ), six tracheae (at 0.1,1 and $10 \mu \mathrm{M}$ ) or 11 different tracheae (at control, 1 and $10 \mathrm{nM}$ ); and c, d) three tracheae (one ex-smoker and two nonsmokers). *: $p<0.05$ and ${ }^{* *}: p<0.01$, significant difference from viral infection alone $(a, c$ and $d)$ and from vehicle $(b)$ alone.

after infection contained significant levels of RV14 (fig. 1d). The viral titre levels in the ASL increased significantly with time for the first 3 days $(72 \mathrm{~h}$ ) (using ANOVA, $\mathrm{p}<0.05$ ). Treatment of the cells with tiotropium $(0.1 \mu \mathrm{M})$ significantly decreased the viral titres of RV14 in the ASL from $24 \mathrm{~h}$ (1 day) after infection compared with the titres in the cells treated with vehicle (fig. 1d).

The viral titre levels in the ASL from the cells on filter membranes were lower than those in the supernatant fluids of the cells cultured in tubes by rolling $(n=3, p<0.05$; data not shown). The potency of the inhibitory effects of tiotropium in the cells on filter membranes was similar to that in the cells cultured in tubes (data not shown).

\section{Effects of tiotropium on viral RNA by real-time RT-PCR}

Further evidence of the inhibitory effects of tiotropium on RV14 RNA replication in human tracheal epithelial cells was provided by real-time quantitative RT-PCR analysis. The RNA extraction was performed at 1 and 3 days ( 24 and $72 \mathrm{~h}$ ) after RV14 infection. RV14 RNA was consistently observed in the cells from 1 day ( $24 \mathrm{~h}$ ) after infection, and the levels increased between 1 and 3 day (24and $72 \mathrm{~h}$ ) after infection (fig. 2). In preliminary experiments, the maximum RV RNA replication was observed at 3 days (72 h) after infection (data at $120 \mathrm{~h}$ not shown), whereas RV14 RNA was not observed in the cells before infection (data not shown). Tiotropium $(0.1 \mu \mathrm{M})$ decreased the RV14 RNA levels at 1 day $(24 \mathrm{~h})$ and 3 days (72 h) after infection (fig. 2).

\section{Effects of tiotropium on susceptibility to RV infection}

Treatment of the cells with tiotropium $(0.1 \mu \mathrm{M})$ decreased the susceptibility of the cells to RV14 infection. When viral release was measured using supernatant fluids collected 3 days (72 h) after RV14 infection, the minimum dose of RV14 necessary to cause infection in the cells treated with tiotropium $(0.1 \mu \mathrm{M}$ at 




FIGURE 2. Replication of viral RNA in human tracheal epithelial cells at 1 and 3 days (24 and $72 \mathrm{~h}$, respectively) after infection with rhinovirus (RV) type- 14 in the presence of tiotropium $(0.1 \mu \mathrm{M})$ or a vehicle $(0.001 \%$ of $0.01 \mathrm{~N} \mathrm{HCl})$, as detected by real-time quantitative RT-PCR. The epithelial cells isolated from the same donors were treated with either tiotropium or vehicle. The results are expressed as the relative amount of RNA expression compared with the maximal RV RNA levels at 3 days $(72 \mathrm{~h}$ ) in the cells treated with vehicle. Results are given as mean \pm SEM from five samples (one ex-smoker and four nonsmokers). *: $p<0.05$, significant difference from treatment with vehicle.

$72 \mathrm{~h}, \mathrm{n}=5)$ was significantly higher than in the cells treated with the vehicle $(0.001 \%$ of $0.01 \mathrm{~N} \mathrm{HCl}, \mathrm{n}=5)$ only $(3.3 \pm 0.2$ versus $2.2 \pm 0.2 \log$ TCID50 units $\cdot \mathrm{mL}^{-1}$, respectively; $\left.\mathrm{p}<0.05\right)$.

\section{Effects of tiotropium on the expression of ICAM-1}

Tiotropium $(0.1 \mu \mathrm{M}, 72 \mathrm{~h})$ reduced baseline ICAM-1 mRNA expression in the cells by $\sim 40 \%$ compared with the levels in cells treated with the vehicle only $(0.001 \%$ of $0.01 \mathrm{~N} \mathrm{HCl})$ before RV14 infection (fig. 3a). Furthermore, the concentrations of sICAM-1 in the supernatant fluids from the cells treated with tiotropium $(0.1 \mu \mathrm{M})$ were significantly lower than those from the cells treated only with the vehicle before RV14 infection (fig. 3b).

\section{Effects of tiotropium on the acidification of endosomes}

Acidic endosomes in human tracheal epithelial cells were stained green with LysoSensor DND-189 (fig. 4), as shown previously [6]. Treatment with the vehicle $(0.001 \%$ of $0.01 \mathrm{~N}$ $\mathrm{HCl})$ for 3 days $(72 \mathrm{~h})$ did not change the number of acidic endosomes with green fluorescence in the cells (fig. 4). In contrast, treatment with tiotropium $(72 \mathrm{~h})$ reduced the number of acidic endosomes with green fluorescence in the cells $(0.1$ and $10 \mu \mathrm{M}$; fig. $4 \mathrm{c}$ and $\mathrm{d}$ ).

Likewise, treatment with the vehicle $(0.001 \%$ of $0.01 \mathrm{~N} \mathrm{HCl})$ for 3 days $(72 \mathrm{~h}$ ) did not change the fluorescence intensity from the acidic endosomes compared with the intensity in the cells before any treatment (fig. 5). In contrast, treatment with tiotropium reduced the fluorescence intensity from acidic endosomes in the cells compared with cells treated with vehicle only $(0.001 \%$ of $0.01 \mathrm{~N} \mathrm{HCl})$ or compared with cells before any treatment (fig. 5).

The inhibitory effects of tiotropium on the fluorescence intensity from acidic endosomes were time-dependent, and significant inhibitory effects were observed when the cells
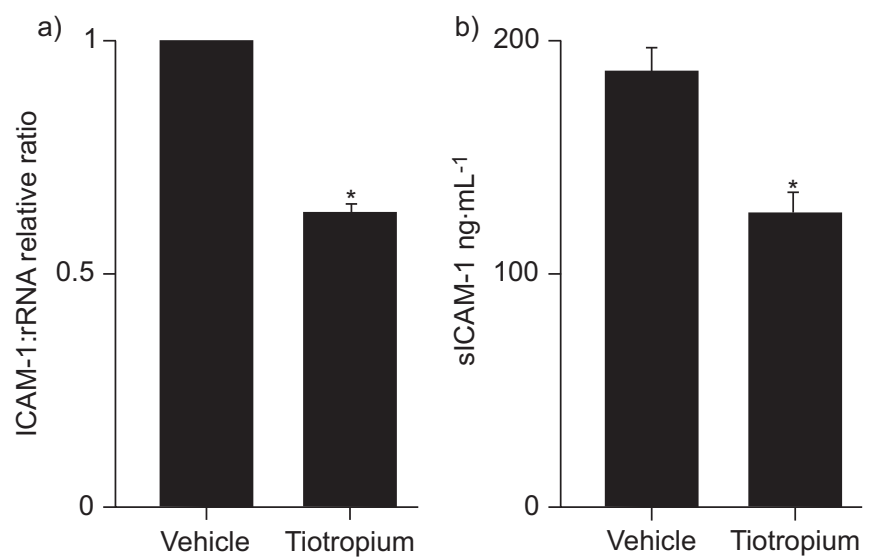

FIGURE 3. a) The expression of intercellular adhesion molecule (ICAM)-1 mRNA before rhinovirus type-14 (RV14) infection in human tracheal epithelial cells treated with tiotropium $(0.1 \mu \mathrm{M}, 72 \mathrm{~h})$ or vehicle $(0.001 \%$ of $0.01 \mathrm{~N} \mathrm{HCl})$, as detected by real-time quantitative RT-PCR). The epithelial cells isolated from the same donors were treated with either tiotropium or vehicle. ICAM-1 mRNA was normalised to the constitutive expression of ribosomal RNA (rRNA). The expression of ICAM-1 mRNA in the cells treated with vehicle was set to 1.0. b) The soluble form of ICAM-1 (SICAM-1) concentrations in supernatant fluids before RV14 infection in human tracheal epithelial cells treated with tiotropium $(0.1 \mu \mathrm{M}, 72 \mathrm{~h})$ or vehicle $(0.001 \%$ of $0.01 \mathrm{~N} \mathrm{HCl})$, as detected by enzyme immunoassay. The concentrations of sICAM-1 in the supernatant fluids are expressed as $\mathrm{ng} \cdot \mathrm{mL}^{-1}$. The data are reported as mean \pm SEM from five different tracheae (one ex-smoker and four nonsmokers). *: $p<0.05$, significant differences from control values.

were treated with tiotropium $(0.1 \mu \mathrm{M})$ for $\geqslant 24 \mathrm{~h}$ (fig. 5a). The maximum inhibitory effect was obtained when the cells were treated with tiotropium for 3 days $(72 \mathrm{~h}$, fig. $5 \mathrm{a})$. The inhibitory effects of tiotropium on the fluorescence intensity from acidic endosomes were also dose dependent. Significant
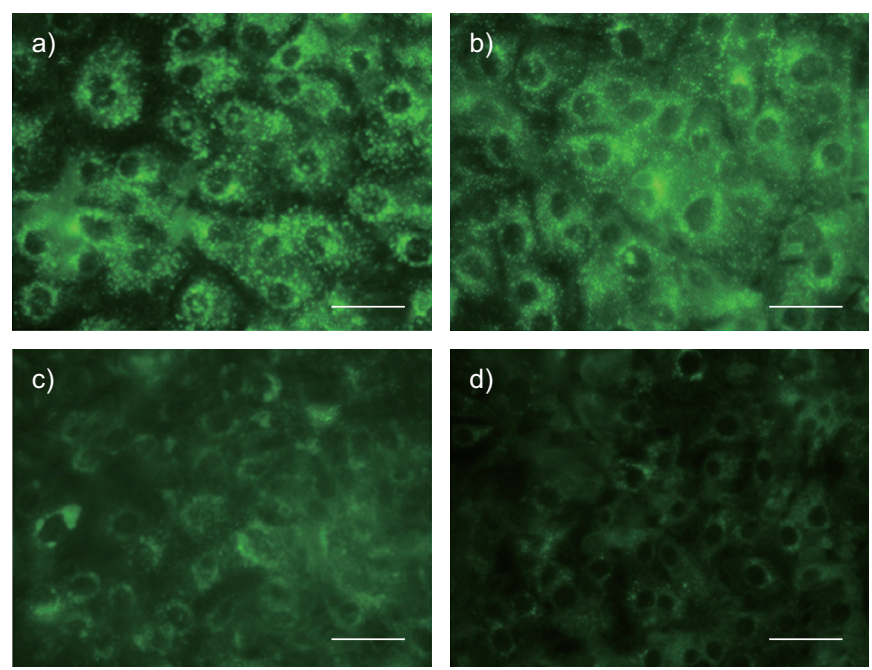

FIGURE 4. Changes in the distribution of acidic endosomes with green fluorescence in human tracheal epithelial cells a) before treatment, c) after 3 days (72 h) of treatment with $0.1 \mu \mathrm{M}$ or d) $10 \mu \mathrm{M}$ tiotropium, and b) vehicle $(0.001 \%$ of $0.01 \mathrm{~N} \mathrm{HCl}$ ). Data are representative of five different experiments (two ex-smokers and three nonsmokers). Scale bar $=100 \mu \mathrm{m}$. 

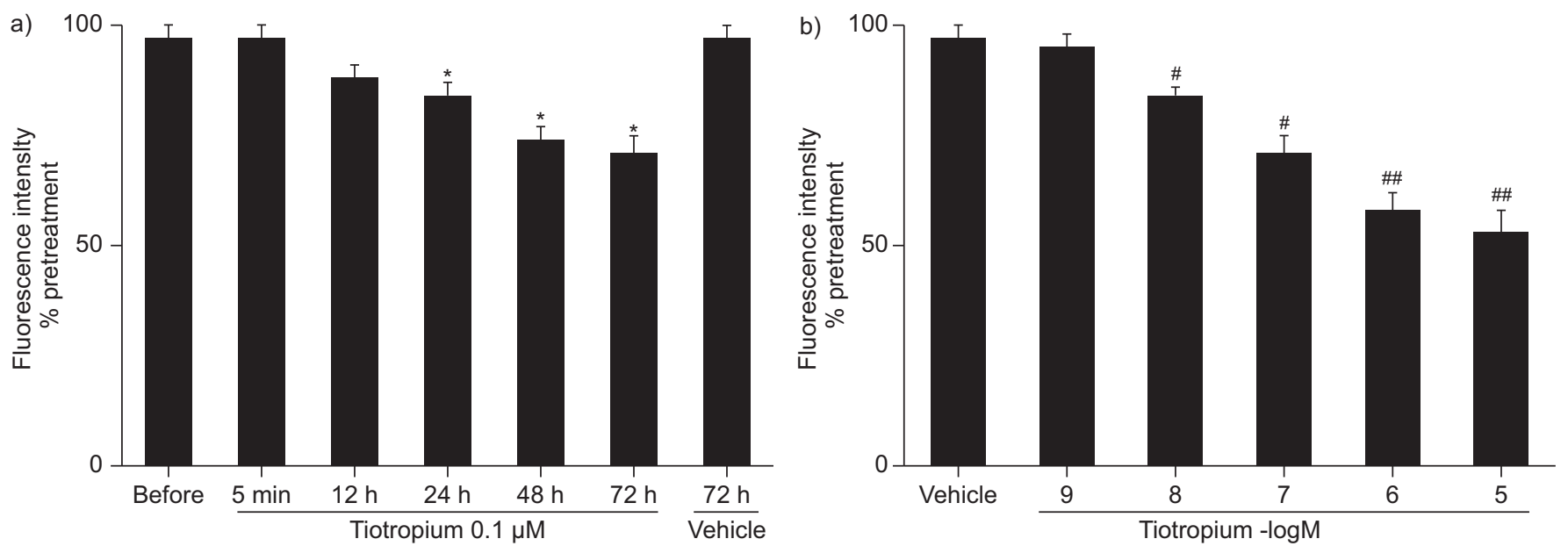

FIGURE 5. a) Time course of the effects of tiotropium $(0.1 \mu \mathrm{M})$ on the fluorescence intensity of acidic endosomes in cells treated for times ranging from 0 (before) to 3 days $(72 \mathrm{~h})$ after treatment and the fluorescence intensity in cells treated with a vehicle $(0.001 \%$ of $0.01 \mathrm{~N} \mathrm{HCl})$ for 3 days $(72 \mathrm{~h})$. b) Dose-response effects of tiotropium $(0.1 \mu \mathrm{M})$ on the fluorescence intensity of acidic endosomes 3 days $(72 \mathrm{~h})$ after treatment. The cells were treated with tiotropium or vehicle $(0.001 \%$ of $0.01 \mathrm{~N} \mathrm{HCl})$ for 3 days $(72 \mathrm{~h})$. The results are reported as mean \pm SEM from five different tracheae (two ex-smokers and three nonsmokers). ${ }^{*}$ : $p<0.05$, significant difference from before any treatment; ${ }^{*}: p<0.05$ and ${ }^{\# \#}: p<0.01$, significant difference from vehicle alone.

inhibitory effects were observed at $10 \mathrm{nM}$, and the maximum inhibitory effect was obtained at $10 \mu \mathrm{M}$ (fig. 5b).

\section{Effects of tiotropium on cytokine production}

Tiotropium $(0.1 \mu \mathrm{M})$ reduced the baseline secretion of IL-1 $\beta,-6$, and -8 for $24 \mathrm{~h}$ before RV14 infection when compared with the levels in cells treated with vehicle only $(0.001 \%$ of $0.01 \mathrm{~N} \mathrm{HCl})$ (fig. 6). RV14 infection increased the secretion of IL-1 $\beta,-6$ and -8 . The maximum secretion was observed at 1 day $(24 \mathrm{~h})$ after RV14 infection for IL-6 and -8 and at 3 days (72 h) after infection for IL$1 \beta$. Tiotropium $(0.1 \mu \mathrm{M})$ also reduced the RV14 infection-induced secretion of IL- $1 \beta,-6$, and -8 when compared with the secretion levels in cells treated with vehicle only (fig. 6). Furthermore, at a concentration of $33 \mathrm{pM}$, which corresponds to the plasma concentration after inhalation of $18 \mu \mathrm{g}$ of tiotropium (clinical dose) [20], tiotropium when compared with vehicle treated cells $(\mathrm{n}=3, \mathrm{p}<0.05)$, reduced the RV14 infection-induced secretion of IL-1 $\beta\left(192 \pm 5\right.$ versus $153 \pm 4 \mathrm{pg} \cdot \mathrm{mL}^{-1}$, respectively, $72 \mathrm{~h}$ after infection), IL-6 (206 \pm 8 versus $146 \pm 5 \mathrm{pg} \cdot \mathrm{mL}^{-1}$, respectively, $24 \mathrm{~h}$ after infection), and IL-8 (1062 \pm 43 versus $961 \pm 33 \mathrm{pg} \cdot \mathrm{mL}^{-1}$, respectively, $24 \mathrm{~h}$ after infection).

The secretion levels of IL-1 $\beta,-6$ and -8 in the supernatant fluids of the cells from the 13 ex-smokers did not differ from the levels of the 37 patients who had never smoked (data not shown). Likewise, the secretion levels of IL- $1 \beta,-6$ and -8 in the supernatant fluids of the cells from the eight patients complicated with COPD did not differ from the levels of the 42 patients without COPD complications (data not shown).
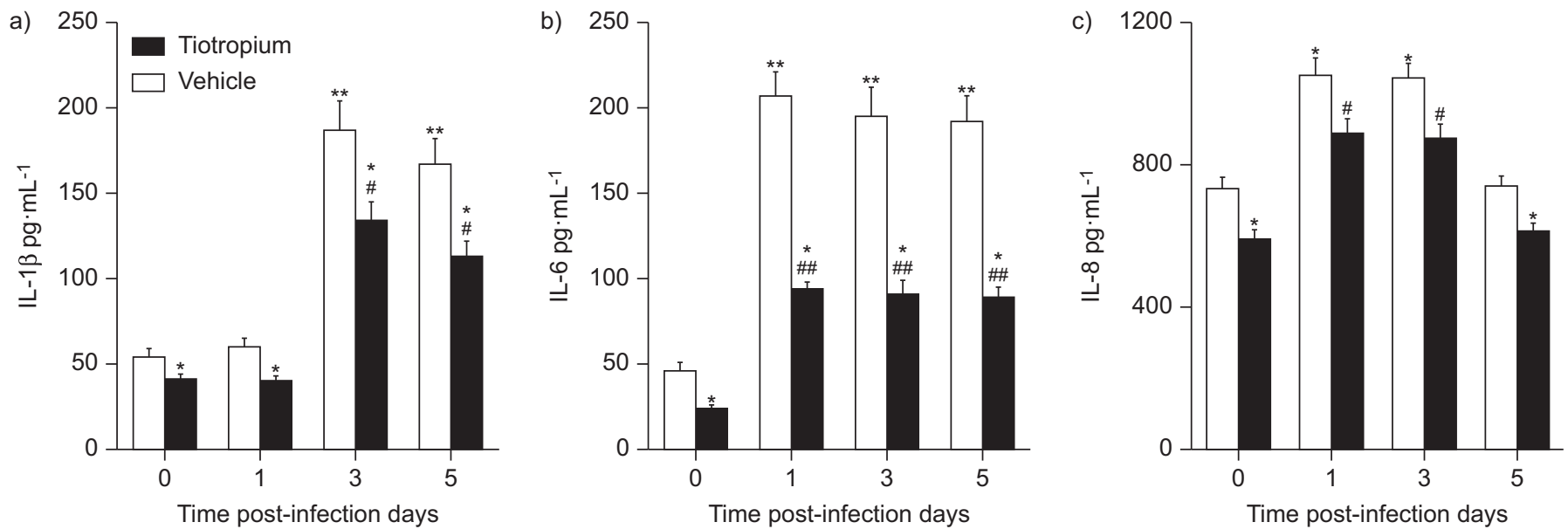





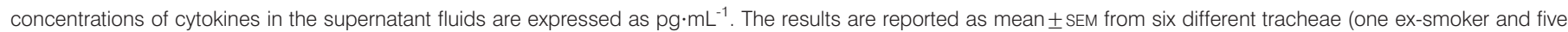

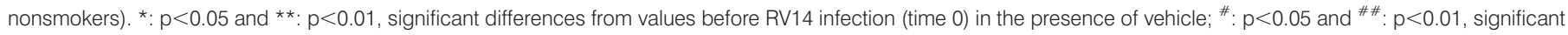
differences from RV14 infection alone after infection. 

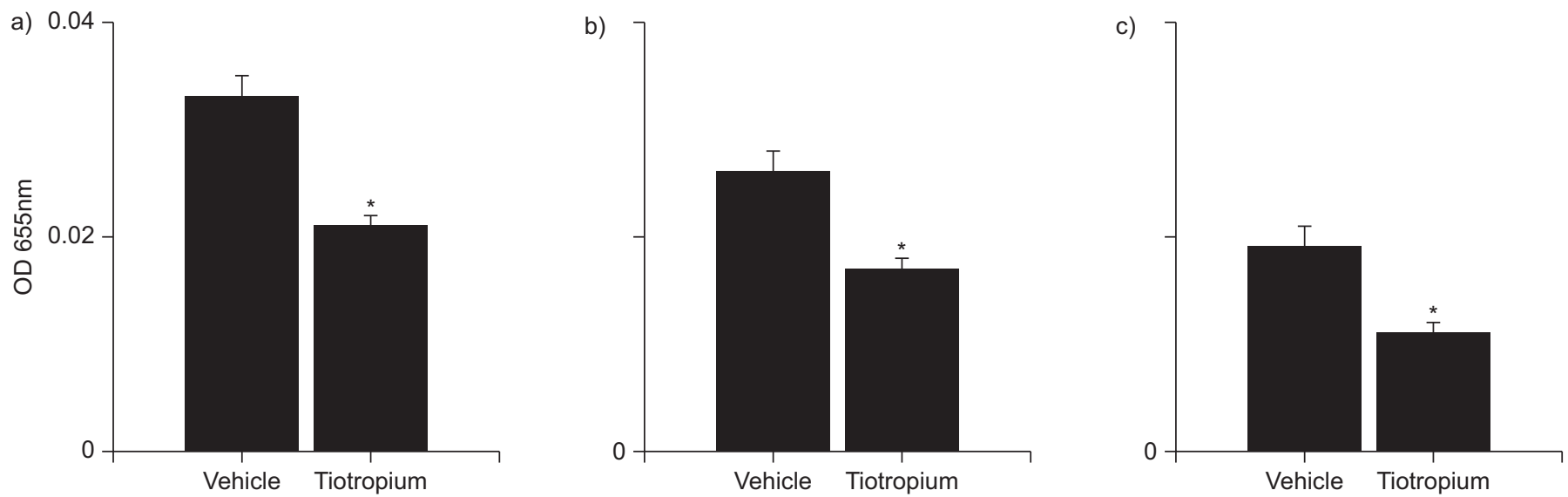

FIGURE 7. Amount of a) p50, b) p65 and c) c-Rel in the nuclear extracts of human tracheal epithelial cells treated with tiotropium $(0.1 \mu \mathrm{M})$ or a vehicle $(0.001 \%$ of $0.01 \mathrm{~N} \mathrm{HCl}$ ) for 3 days $(72 \mathrm{~h}$ ) before rhinovirus type-14 (RV14) infection. The results are expressed as optical density (OD) and are reported as mean \pm SEM from five different tracheae (two ex-smokers and three nonsmokers). *: $p<0.05$, significant differences from control (vehicle) values before RV14 infection.

\section{Effects on NF- $\kappa B$}

Tiotropium $(0.1 \mu \mathrm{M}, 72 \mathrm{~h})$ significantly reduced the amount of the p50, p65 and c-Rel subunits of NF-кB in the nuclear extracts of the cells cultured under stationary conditions before RV14 infection (fig. 7). This was also found in cells cultured by rolling in the absence of RV14 infection. Under rolling conditions, the amounts of p50, p65 and c-Rel in the nuclear extracts of cells treated with tiotropium $(0.1 \mu \mathrm{M})$ OD readings $(0.018 \pm 0.001,0.014 \pm 0.001$ and $0.008 \pm 0.001$ OD for p50, p65 and $c-R e l$, respectively; $\mathrm{p}<0.05)$ were significantly lower than those of the cells treated with vehicle $(0.001 \%$ of $0.01 \mathrm{~N} \mathrm{HCl})$ for 3 days $(0.031 \pm 0.002,0.024 \pm 0.001$ and $0.017 \pm 0.001$ OD for p50, p65 and c-Rel, respectively) in the absence of RV14 infection. Likewise, in cells cultured under stationary conditions before RV14 infection, tiotropium (0.1 and $10 \mu \mathrm{M}, 72 \mathrm{~h}$ ) significantly reduced $\mathrm{p}-\mathrm{I \kappa \textrm {B }}-\alpha$ levels in the cellular proteins (fig. $8 \mathrm{~b})$. In contrast, tiotropium $(0.1$ and $10 \mu \mathrm{M}, 72 \mathrm{~h})$ significantly increased the amount of IкB- $\alpha$ before infection (fig. $8 \mathrm{c}$ ).

\section{DISCUSSION}

In the present study, we have shown that the long-acting anticholinergic agent tiotropium reduced the titres of a major group RV, RV14, in the supernatant fluids of primary cultures of human tracheal epithelial cells cultured in tubes [6] and in the ASL of cells cultured on filter membranes with physiological differentiation [15]. Tiotropium also reduced RNA replication of the virus in primary cultures of cells cultured in tubes. Pretreatment with tiotropium reduced the mRNA and protein expression levels of ICAM-1, the receptor for the major group of RVs [10], before RV14 infection. The minimum dose of RV14 necessary to cause infection in cells treated with tiotropium was significantly higher than that in cells treated a)

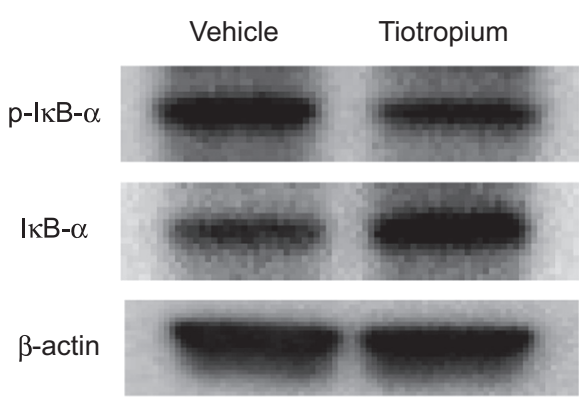

b) 1.50

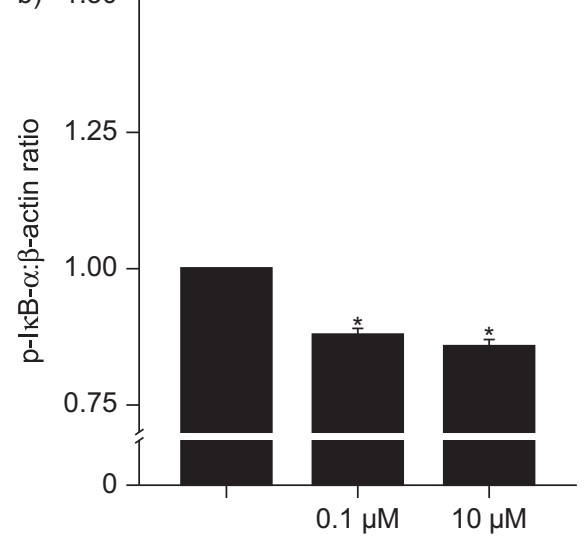

Vehicle
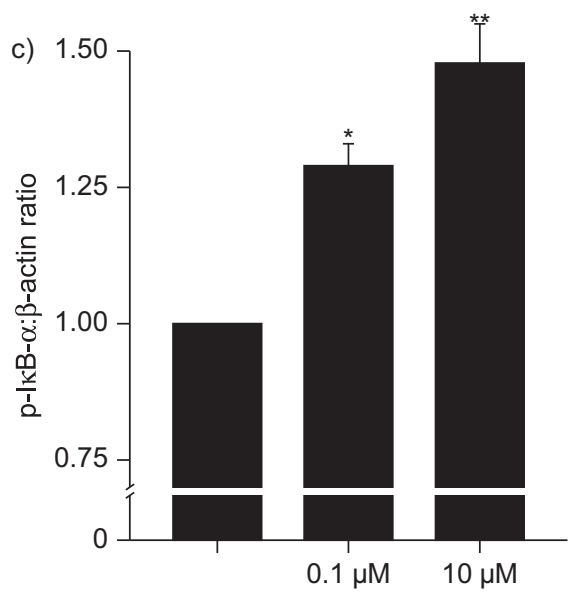

Vehicle

Tiotropium

FIGURE 8. a) Representative data on the cytosolic amounts of phosphorylated $1 \kappa B-\alpha(p-\mid \kappa B-\alpha)$, IкB- $\alpha$ or $\beta$-actin in human tracheal epithelial cells before rhinovirus type14 (RV14) infection in the presence of tiotropium $(10 \mu \mathrm{M})$ or a vehicle $(0.1 \%$ of $0.01 \mathrm{~N} \mathrm{HCl})$. The cytosolic amounts of b) $\mathrm{p}-\mathrm{l} \mathrm{kB}-\alpha$ and $\mathrm{c})$ I $\mathrm{kB}-\alpha$ in cells treated with tiotropium $(0.1 \mu \mathrm{M}$ and $10 \mu \mathrm{M})$ or a vehicle $(0.001 \%$ of $0.01 \mathrm{~N} \mathrm{HCl})$. The data were obtained by dividing the results in each culture condition by the results for $\beta$-actin. The cytosolic amounts of $\mathrm{p}-\mathrm{I} \mathrm{KB}-\alpha$ and $\mathrm{IKB}-\alpha$ in the cells treated with vehicle before RV infection were set to 1.0. The results are means \pm SEM from three different experiments (one ex-smoker and two nonsmokers). *: $p<0.05$ and **: $p<0.01$, significant differences from control values (vehicle) before RV14 infection. 
with the vehicle alone. These findings suggest that tiotropium might inhibit RV14 infection partly by reducing the production of its receptor, ICAM-1.

Furthermore, treatment with tiotropium reduced the number and fluorescence intensity of acidic endosomes, from which RV RNA enters the cytoplasm [3,9], and this reduction was dose- and time-dependent. Inhibition of RNA entry into the cytoplasm by reducing numbers of acidic endosomes may reduce the number of virions that enter the cytoplasm. Tiotropium may also inhibit RV14 infection in part by inhibiting RV RNA entry from acidic endosomes into cells.

Human embryonic fibroblast cells did not exhibit any morphological changes that indicated the presence of RV14 when supernatant fluids collected $1 \mathrm{~h}$ after infection were added to the fibroblast cells. In contrast, supernatant fluids collected $12 \mathrm{~h}$ after infection produced morphological changes in the cells, indicating the presence of RV $[3,16,17]$. These findings suggest that supernatant fluids collected $12 \mathrm{~h}$ after infection contained significant amounts of RV14 virions that were newly produced after infection, as reported previously [6].

Furthermore, in the tracheal cells from all of the subjects whose cells were infected with RV, the supernatant fluids collected during 1-3 days (24-72 h) after infection contained consistent levels of RV14. These findings suggest that the tracheal epithelial cells from all of the subjects were constantly infected with RV14.

Maximum serum concentrations of tiotropium have been reported to be $16 \mathrm{ng} \cdot \mathrm{L}^{-1}(33 \mathrm{pM})$ in stable COPD patients given a single $18 \mu \mathrm{g}$ inhaled dose, which is the clinical dose [20]. In the present study, the inhibitory effects of tiotropium on virus release were concentration-dependent, and significant effects were obtained even at $33 \mathrm{pM}$. Furthermore, we demonstrated that tiotropium also reduced release of IL-1 $\beta$, -6 and -8 , even at a low concentration ( $33 \mathrm{pM})$. The inhibitory effects of tiotropium on RV14 infection that were observed in the present study are consistent with a previous report that tiotropium inhibits cholinergic contractile responses in human bronchi at concentrations $>100 \mathrm{pM}$ [21]. These findings suggest that tiotropium may inhibit RV14 infection and airway inflammation at the doses given safely clinically, and these effects may be relevant to the clinical benefits of tiotropium in the treatment of COPD patients.

In the present study, the amount of virus in the supernatant fluids from cells cultured in tubes by rolling was larger than in the ASL taken from physiological differentiated cells [15] cultured on filter membranes under stationary conditions. These findings are consistent with those previously reported $[3,6]$. The differences in the virus titres may be associated with the characteristics of RV proliferation; culture conditions with rolling may be more suitable for RV proliferation than stationary conditions [3]. Epithelial cells cultured on filter membranes show differentiated features, such as a multilayered structure, increased ion transport and increased protein production [15]. Tiotropium reduced the amount of virus in the ASL from cells cultured on filter membranes with a potency similar to that observed in the supernatant fluids of cells cultured in tubes. These findings suggest that tiotropium may inhibit RV14 infection in airway epithelial cell layers under physiological conditions.

Tiotropium reduced RV14 virus titres in supernatant fluids 1, 3 and 5 days (24, 72 and $120 \mathrm{~h}$, respectively), after infection when cells were pretreated with tiotropium and tiotropium was removed just prior to virus infection. By contrast, RV14 titres at 7 days after infection in the cells pretreated with tiotropium prior to infection did not differ from those in the cells pretreated with vehicle. These findings suggest that the inhibitory effects of tiotropium on the cells might continue for 5 days, even after removal of tiotropium from the medium, and that tiotropium may not interact directly with the virus particles.

Neutrophilic inflammation in exacerbations of COPD is suggested to be associated with a variety of mediators, including IL-6, after RV infection [4]. Tiotropium reduces the release of IL- 6 and -8 induced by RS virus infection in cells of the human epithelial cell line Hep2 [14]. Tiotropium also inhibits the production of pro-inflammatory cytokines and monokines, including IL-6 in mouse lungs [7] and a human bronchial epithelial cell line that was induced by acetylcholine [22]. Furthermore, tiotropium reduces the number of neutrophils in bronchoalveolar lavage fluids in a mouse model of COPD [7] and inhibits neutrophil elastase-induced goblet cell metaplasia in mice [2]. These findings from in vitro, in vivo and clinical studies suggest that tiotropium may reduce the production and release of inflammatory factors and the accumulation of inflammatory cells in the lung in response to stimuli, including virus infection. Although it is unclear if tiotropium has anti-inflammatory effects in COPD patients [8], these findings suggest the possibility that tiotropium may modulate airway inflammation.

The results in the present study, in which tiotropium reduced RV14 infection-induced production of IL-1 $\beta,-6$ and -8 , are consistent with those of previous reports. Similar to the inhibitory effects of glucocorticoid, lansoprazole and procaterol $[6,13]$, tiotropium may also modulate airway inflammation that is induced by $\mathrm{RV}$ infection.

ICAM-1 also plays a vital role in the recruitment and migration of immune effector cells to the sites of local inflammation that are observed in patients with COPD [23]. The inhibitory effects of tiotropium on ICAM-1, as shown in this study, may also be associated with the inhibition exacerbations of COPD [1].

RVs, a major viral group, enter the cytoplasm of infected cells after binding to their receptor, ICAM-1 [10]. In the present study, tiotropium was found to reduce ICAM-1 expression in the primary cultures of human tracheal epithelial cells, as shown in the epithelial cell line Hep2 [14]. The inhibitory effects of tiotropium on ICAM-1 expression in human tracheal epithelial cells may be associated with the inhibitory effects of tiotropium on RV14 infection. This phenomenon has been previously reported for the inhibitory effects of various agents, including dexamethasone, erythromycin, the proton pump inhibitor lansoprazole, and the $\beta_{2}$-agonist procaterol $[6,13]$.

The endosomal $\mathrm{pH}$ may be regulated by vacuolar $\mathrm{H}^{+}$-ATPase [24] and by ion transport across $\mathrm{Na}^{+} / \mathrm{H}^{+}$exchangers [25]. The vacuolar $\mathrm{H}^{+}$-ATPase inhibitor bafilomycin and the $\mathrm{Na}^{+} / \mathrm{H}^{+}$ 
exchanger inhibitors 5-(N-ethyl- $N$-isopropyl) amiloride and $N^{\prime \prime}$-[3-(hydroxymethyl)-5-(1H-pyrrol-1-yl) benzoyl] guanidine methanesulfonate (FR168888) increased endosomal $\mathrm{pH}$ and inhibited RV14 infection in cultured human tracheal epithelial cells [12]. In the present study, tiotropium increased the endosomal $\mathrm{pH}$; however, whether tiotropium inhibits vacuolar $\mathrm{H}^{+}$-ATPase or $\mathrm{Na}^{+} / \mathrm{H}^{+}$exchangers is unknown. Acetylcholine is a physiological stimulus that causes acid secretion in gastric parietal cells through the activation of the $\mathrm{H}^{+} / \mathrm{K}^{+}$-ATPase [26]. A proton pump inhibitor, lansoprazole, inhibits the $\mathrm{H}^{+} / \mathrm{K}^{+}$ATPase and increases the endosomal $\mathrm{pH}$ in human tracheal epithelial cells [13]. Furthermore, a vacuolar $\mathrm{H}^{+}$-ATPase inhibitor, bafilomycin $\mathrm{A}_{1}$, inhibits increases in cytoplasmic $\mathrm{pH}$ that are induced by acetylcholine in cultured rabbit nonpigmented ciliary epithelial cells [27]. These findings suggest the possibility that tiotropium has inhibitory effects on the $\mathrm{H}^{+} / \mathrm{K}^{+}$-ATPase and/or the vacuolar $\mathrm{H}^{+}$-ATPase in airway epithelial cells.

Acidic endosomes could be observed in the cells living on coverslips in Petri dishes under stationary conditions as reported previously [6]. The cells on the coverslips in Petri dishes could not be cultured with rolling. Therefore, we used cells cultured under stationary conditions to measure acidic endosomes in the present study. We did not examine the effects of tiotropium on acidic endosomes in cells cultured by rolling, the method of culture used after RV14 infection, and our results for the effects of tiotropium on acidic endosomes are thus limited by the need for stationary conditions.

In the present study, we examined the effects of tiotropium in cells under stationary conditions and in cells cultured by rolling and found that tiotropium reduced the amount of the p50, p65 and c-Rel subunits of NF- $\mathrm{KB}$ in the nuclear extracts under both conditions. Because the cells were cultured under stationary conditions before RV14 infection and with rolling after infection, these findings suggest that tiotropium inhibits NF- $\kappa B$ activation in cells cultured under either condition. Furthermore, in cells cultured under stationary conditions, tiotropium reduced $\mathrm{p}-\mathrm{I} \kappa \mathrm{B}-\alpha$ levels in the cellular proteins and increased the amount of I $\mathrm{B}-\alpha$ before infection. These findings suggest that tiotropium may inhibit NF- $\mathrm{B}$ activation before and after RV14 infection in the present study.

NF- $\kappa \mathrm{B}$ increases the expression of genes encoding ICAM-1 and various pro-inflammatory cytokines [5]. In the present study, tiotropium reduced the expression of ICAM-1 before RV infection and reduced the secretion of pro-inflammatory cytokines in supernatant fluids before and after RV infection. Tiotropium reduced baseline p50, p65 and c-Rel levels of NF$\kappa B$ before RV infection. Tiotropium also reduced $\mathrm{p}-\mathrm{I} \kappa \mathrm{B}-\alpha$ levels and increased I $\mathrm{KB}-\alpha$ levels in the cellular protein pool before RV14 infection. The inhibitory effects of tiotropium on NF- $\kappa$ B activation observed in this study are consistent with those observed in human airway epithelial cells $[5,6]$. These findings suggest that tiotropium may reduce the expression of ICAM-1 in cells and the secretion of pro-inflammatory cytokines partly through the reduction of NF- $\mathrm{KB}$ activation.

Tiotropium alone did not change cell viability, including cell number, as assessed by the exclusion of trypan blue and the $\mathrm{LDH}$ concentrations in the supernatant fluids. However, tiotropium reduced $\mathrm{NF}-\kappa \mathrm{B}$ activation before $\mathrm{RV}$ infection. These findings suggest that reduced cytokine release and ICAM-1 expression may be partly associated with the inhibition of NF- $\mathrm{KB}$ activation but not cell injury.

In the present study, RV14 titre levels in the supernatant fluids of the cells from the eight patients complicated with COPD did not differ from those of the 42 patients without COPD. Likewise, RV14 titre levels in the supernatant fluids of the cells from the 10 patients with lung diseases (lung cancer, IPF, pneumonia or IPAH) did not differ from the titre levels of the cells from the other 40 patients without lung diseases. Because we isolated the cells from human tracheae after death, the conditions before death, at the time of death, and between the time of death and cell isolation may have masked the characteristic features of the cultured cells as they functioned in the lung diseases in this study. However, further studies are needed to clarify the difference in the magnitude of $R V$ replication in cells from patients, including COPD patients.

The amount of cytokine release after RV infection did not differ between smokers and nonsmokers. Conditions before death, at the time of death, and between the time of death and the time of cell isolation may have again masked the cell conditions.

$\mathrm{RV}$ infections have been reported to be confined to the upper airways. However, several reports have demonstrated that RV can be cultured from sputum and cells in bronchoalveolar lavage fluids from human subjects after experimental infection [28]. RV can also be detected by RT-PCR in cells in bronchial tissues after inoculation [29]. Furthermore, increased release of RV and cytokines, including IL-6 and -8, in tracheal and bronchial epithelial cells from COPD patients has been reported [30], although we could not find differences in RV14 titres in supernatant fluids between COPD patients and non-COPD subjects. These findings suggest that the RV14 infection model used in this study with human tracheal epithelial cells could be a valid model.

In summary, this is the first report that the long-acting anticholinergic agent tiotropium reduces RV14 titres in supernatant fluids, reduces RV RNA replication in cultured human tracheal epithelial cells, and decreases the susceptibility of the cells to RV14 infection. This effect may occur partly through the reduced expression of ICAM-1, the receptor for the major group of RVs, and a reduction in the number of acidic endosomes from which RV RNA enters the cytoplasm. Tiotropium reduced baseline and RV infection-induced release of IL-1 $\beta,-6$ and -8 in the supernatant fluids. Tiotropium may inhibit infection by the major group of RVs and modulate inflammatory responses in the airways after RV infection.

\section{SUPPORT STATEMENT}

This study was funded by Health, Labour and Welfare Sciences Research Grants for Research on Measures for Intractable Diseases [H20 nanchi ippan 035] from the Japanese Government and was supported by Nippon Boehringer-Ingelheim, Co. Ltd.

\section{STATEMENT OF INTEREST}

A statement of interest for M. Yamaya and H. Kubo, and for the study itself can be found at www.erj.ersjournals.com $/ \mathrm{site} / \mathrm{misc} /$ statements. xhtml 


\section{REFERENCES}

1 Tashkin DP, Celli B, Senn S, et al. A 4-year trial of tiotropium in chronic obstructive pulmonary disease. N Engl J Med 2008; 359: 1543-1554.

2 Arai N, Kondo M, Izumo T, et al. Inhibition of neutrophil elastaseinduced goblet cell metaplasia by tiotropium in mice. Eur Respir J 2010; 35: 1164-1171.

3 Turner RB, Couch RB. Rhinoviruses. In: Knipe DM, Howley PM, eds. Fields Virology. 5th Edn. Philadelphia, Lippincott Williams and Wilkins, 2006; pp. 895-909.

4 Seemungal T, Harper-Owen R, Bhowmik A, et al. Detection of rhinovirus in induced sputum at exacerbation of chronic obstructive pulmonary disease. Eur Respir J 2000; 16: 677-683.

5 Zhu Z, Tang W, Ray A, et al. Rhinovirus stimulation of interleukin-6 in vivo and in vitro. Evidence for nuclear factor kappa B-dependent transcriptional activation. J Clin Invest 1996; 97: 421-430.

6 Yamaya M, Nishimura H, Hatachi Y, et al. Procaterol inhibits rhinovirus infection in primary cultures of human tracheal epithelial cells. Eur J Pharmacol 2011; 650: 431-444.

7 Wollin L, Pieper MP. Tiotropium bromide exerts anti-inflammatory activity in a cigarette smoke mouse model of COPD. Pulm Pharmacol Ther 2010; 23: 345-354.

8 Powrie DJ, Wilkinson TMA, Donaldson GC, et al. Effect of tiotropium on sputum and serum inflammatory markers and exacerbations in COPD. Eur Respir J 2007; 30: 472-478.

9 Casasnovas JM, Springer TA. Pathway of rhinovirus disruption by soluble intercellular adhesion molecule 1 (ICAM-1): an intermediate in which ICAM-1 is bound and RNA is released. J Virol 1994; 68: 5882-5889.

10 Greve JM, Davis G, Meyer AM, et al. The major human rhinovirus receptor is ICAM-1. Cell 1989; 56: 839-847.

11 Pérez L, Carrasco L. Entry of poliovirus into cells does not require a low-pH step. J Virol 1993; 67: 4543-4548.

12 Suzuki T, Yamaya M, Sekizawa $K$, et al. Bafilomycin $A_{1}$ inhibits rhinovirus infection in human airway epithelium: effects on endosome and ICAM-1. Am J Physiol Lung Cell Mol Physiol 2001; 280: L1115-L1127.

13 Sasaki T, Yamaya M, Yasuda $H$, et al. The proton pump inhibitor lansoprazole inhibits rhinovirus infection in cultured human tracheal epithelial cells. Eur J Pharmacol 2005; 509: 201-210.

14 Iesato K, Tatsumi K, Saito K, et al. Tiotropium bromide attenuates respiratory syncytial virus replication in epithelial cells. Respiration 2008; 76: 434-441.
15 Yamaya M, Finkbeiner WE, Chun SY, et al. Differentiated structure and function of cultures from human tracheal epithelium. Am J Physiol 1992; 262: L713-L724.

16 Numazaki Y, Oshima T, Ohmi A, et al. A microplate method for isolation of viruses from infants and children with acute respiratory infections. Microbiol Immunol 1987; 31: 1085-1095.

17 Condit RC. Principles of virology. In: Knipe DM, Howley PM, eds. Fields Virology. 5th Edn. Philadelphia, Lippincott Williams and Wilkins, 2006; pp. 25-57.

18 Nolan T, Hands RE, Bustin SA. Quantification of mRNA using real-time RT-PCR. Nat Protoc 2006; 1: 1559-1582.

19 Nakayama K, Jia YX, Hirai H, et al. Acid stimulation reduces bactericidal activity of surface fluid in cultured human airway epithelial cells. Am J Respir Cell Mol Biol 2002; 26: 105-113.

20 Hvizdos KM, Goa KL. Tiotropium bromide. Drugs 2002; 62: 1195-1203.

21 Takahashi T, Belvisi MG, Patel H, et al. Effect of Ba 679 BR, a novel long-acting anticholinergic agent, on cholinergic neurotransmission in guinea pig and human airways. Am J Respir Crit Care Med 1994; 150: 1640-1645.

22 Profita M, Bonanno A, Siena L, et al. Acetylcholine mediates the release of IL-8 in human bronchial epithelial cells by a NFKB/ERKdependent mechanism. Eur J Pharmacol 2008; 582: 145-153.

23 Riise GC, Larsson S, Lofdahl CG, et al. Circulating cell adhesion molecules in bronchial lavage and serum in COPD patients with chronic bronchitis. Eur Respir J 1994; 7: 1673-1677.

24 Mellman I, Fuchs R, Helenius A. Acidification of the endocytic and exocytic pathways. Ann Rev Biochem 1986; 55: 663-700.

25 Marshansky V, Vinay P. Proton gradient formation in early endosomes from proximal tubes. Biochem Biophys Acta 1996; 1284: 171-180.

26 Yao X, Forte JG. Cell biology of acid secretion by the parietal cell Annu Rev Physiol 2003; 65: 103-131.

27 Hou Y, Wu Q, Delamere NA. $\mathrm{H}^{+}$-ATPase-mediated cytoplasmic $\mathrm{pH}-$ responses associated with elevation of cytoplasmic calcium in cultured rabbit nonpigmented ciliary epithelium. J Membr Biol 2001; 182: 81-90.

28 Gern JE, Galagan DM, Jarjour NN, et al. Detection of rhinovirus RNA in lower airway cells during experimentally-induced infection. Am J Respir Crit Care Med 1997; 155: 1159-1161.

29 Mosser AG, Vrtis R, Burchell L, et al. Quantitative and qualitative analysis of rhinovirus infection in bronchial tissues. Am J Respir Crit Care Med 2005; 171: 645-651.

30 Schneider D, Ganesan S, Comstock AT, et al. Increased cytokine response of rhinovirus-infected airway epithelial cells in chronic obstructive pulmonary disease. Am J Respir Crit Care Med 2010; 182: $332-340$ 